\title{
Evaluation of Sawah Rice Management System in an Inland Valley in Southeastern Nigeria. II: Changes in Soil Physical Properties
}

\author{
John Chukwua Nwite ${ }^{1}$, Charles Arizechukwua Igwe ${ }^{1^{*}}$, Toshiyukib Wakatsuki ${ }^{2}$ \\ ${ }^{1}$ Department of Soil Science, University of Nigeria, Nsukka, Nigeria \\ ${ }^{2}$ Faculty of Agriculture, Kinki University, Nara, Japan \\ E-mail: charigwe1@hotmail.com \\ Received July 18, 2009; revised August 18, 2009; accepted August 28, 2009
}

\begin{abstract}
Establishment of effective sawah management system in parts of southeastern Nigeria may involve the manipulation of certain soil physical properties in form of ecological engineering works. This practice may affect the soil physical properties adversely. The objective of the study were basically to compare the influence of sawah and non sawah water management practices on the soil physical properties following rice cultivation with various inorganic and organic amendments. Parameters determined were soil bulk density, total porosity, moisture contents at field capacity (FC) and wilting point (WP), water-stable aggregates, dispersion ratio (DR), and hydraulic conductivity (Ks). Sawah managed soils reduced significantly the soil bulk density in the first and second year of planting thus increasing the soil total porosity during the same period Moisture content also improved in sawah management while WP increased significantly in the second year of planting. In spite of the destruction of soil structure as a result of cultural practices during rice cultivation the DR is improved on the long run by sawah water management. Moisture contents at FC and WP relates significantly with soil bulk density which also relates negatively with total porosity during the 2 years of cultivation. However, FC and WP may be very good tools in the estimation of bulk density. Again, the amendments were identified as promoting the development of soil aggregates and $K s$ on a long term.
\end{abstract}

Keywords: Water-Stable Aggregates, Bulk Density, Hydraulic Conductivity, Dispersion Ratio, Moisture Content

\section{Introduction}

The term sawah is defined as a leveled rice field surrounded by bunds with inlet and outlet connections to irrigation and drainage canals. It originated from MalayoIndonesian term 'paddi' which means rice plants. However, the term 'paddy' refers to rice grain with husks in the whole of West Africa. Wakatsuki et al. [1] therefore used the term sawah to distinguish between rice grain with husk, rice field and rice plant. Establishment of effective sawah management system for in- creased rice production in southeastern Nigeria involves the manipulation of certain soil physical properties in form of ecological engineering works. This manipulation of soil physical properties may involve deep earth movement and tillage to achieve a better topographic setting and optimal soil physical condition. Wakatsuki and Masunaga [2] remarked that ecological engineering of the inland watershed by the local people are required to increase agricultural productivity. These techniques according to them include leveling, bonding, and construction of canals and head dykes. Most soils in the West African sub-region are highly weathered and very fragile [3-7]. Mbagwu [4] reported that physical degradation of soils in the tropics resulted from soil erosion by water and mechanical land clearing using bulldozers. Lal [8] and Mbagwu et al. [9] showed that this degradation was manifested in high bulk density, low total and macro porosity, reduced water infiltration and transmission rate and low water retention and available water capacity within the root zone.

Rengasamy et al. [10] had earlier indicated that many soils used for irrigated or dry land agriculture are difficult to manage owing to their tendency to develop unsatisfactory structure particularly in their surface layers. Breakdown of aggregates leads to surface crusting, re- 
duced water infiltration, restricted plant establishment and growth. The reason for the breakdown is normally as a result of slaking and dispersion of aggregates. These negative physical conditions of the soils added to poor nutrient status of such soils according to Mbagwu [4] resulted in poor crop-productivity and often abandonment of such lands leading to reduction in resource base of rural farmers.

Nnabude and Mbagwu [11] had used abandoned biological waste to improve the physical condition of some soils used in rice production in southeastern Nigeria. They insisted that application of rice mill waste on a Typic Haplustult in southeastern Nigeria resulted in significant improvement in bulk density, permanent water wilting point and total porosity. The use organic waste to restore the physical condition of soils solves two problems; one is the removal from the environment which they pollute and secondly supply of soil plant nutrient and eventual amelioration of soil physical properties. The use of biological wastes in the management of degraded soils or soils used for sawah rice management production is sustainable $[12,13]$. Most of the previous research where biological wastes were used for sustainable management of soils was mainly on upland and rainfed cultivation. None of these uses have been reported in sawah managed cropping system especially in southeastern Nigeria where these wastes are heaped with problems on the disposal. The objective of the study was therefore to 1) compare the influence of sawah and non sawah water managements on the physical characteristics of the soil, 2) to determine the contributions of the amendments on the soil physical properties and 3) the relationships among the soil physical properties.

\section{Materials and Methods}

\subsection{Location and Field Study}

The location of the study and the field design of this study are already given in the part I of this study [14]. The mineralogy of the soil is mainly kaolinite and the so-called interlayer minerals [15]. The major physical characteristics of the soil are shown (Table 1).

The field, which was under fallow for more than 5 years, was disk-ploughed and disk-harrowed to a depth of about $20 \mathrm{~cm}$ before puddling and treatments. The plot was divided into 2 portions, one part for sawah and the second part for non-sawah water management. In the non-sawah managed field, there was no defined water management and no bunding of plots in the field. Water was allowed to flow in and out as it comes but in the sawah field water was controlled and maintained to an approximate level of between 5 and $10 \mathrm{~cm}$ from two weeks after transplanting to the stage of ripening of the grains. In each of the plots the following treatments, arranged as a Split-Plot on a Randomized Complete Block
Design (RCBD) were as shown (Table 1); each treatment was replicated 3 times and each plot was $6 \mathrm{~m} \times 2.5$ $\mathrm{m}$. The NPK fertilizer consisted of $400 \mathrm{~kg} / \mathrm{ha}$ as compound fertilizer, poultry dropping was applied at the rate of 5 tons/ha and Rice husk dust applied at 10 tons/ha. The RD on decomposition is widely applied by local farmers as source of plant nutrient. The nutrient contents of these organic amendments were determined. The mature $\mathrm{PD}$ and $\mathrm{RD}$ were spread on the plots that received them and incorporated manually into the top $20 \mathrm{~cm}$ soil depth 2 weeks before planting. All amendments were applied only in 2004 and their residual effect maintained for the 2 years.

The test crop was a high yielding rice variety Oryza sativa var. Tox 3108. This cultivar is widely used by farmers in the area. This was first planted in a nursery field and later transplanted to the main fields after 4 weeks in nursery. At maturity rice grains were harvested dried and yield computed at $90 \%$ dry matter content. This was done for the two years (2004 and 2005). At the end of each harvest soil samples were collected from each replicate of every plot for physical analyses.

\subsection{Laboratory Methods}

Particle size distribution of the less than 2-mm fine earth

Table 1. Some physical properties of the top soil $(0-20 \mathrm{~cm})$ before ploughing and amendment.

\begin{tabular}{lc}
\hline Soil Property & Value \\
\hline Clay\% & 10 \\
Silt\% & 21 \\
Total sand \% & 69 \\
Textural class & $\mathrm{SL}$ \\
Organic Carbon\% (C) & 1.61 \\
Gravimetric moisture content (\%) at & \\
$-0.1 \mathrm{MPa}$ (Field capacity) FC & 27 \\
$-1.5 \mathrm{MPa}$ (Permanent wilting point) $\mathrm{PWP}$ & 9.2 \\
Saturated hydraulic conductivity $K_{s}\left(\mathrm{~cm} \mathrm{~h}^{-1}\right)$ & 7.0 \\
Bulk density Mg/m & \\
Total porosity\% & 1.29 \\
Mean-weight diameter (MWD) $\mathrm{mm}$ & 51.2 \\
\hline
\end{tabular}

Table 2. Treatment combinations and their symbols.

\begin{tabular}{lcl}
\hline I & F & $\begin{array}{l}\text { NPK Fertilizer (20:10:10). Locally recommended } \\
\text { rate for rice }\end{array}$ \\
\hline II & PD & Poultry droppings \\
III & RD & Rice husk dust \\
IV & RD + PD & Rice husk dust + Poultry droppings \\
V & PD + F & Poultry droppings + NPK Fertilizer \\
VI & RD + F & Rice husk dust + NPK Fertilizer \\
VII & F + PD + & NPK Fertilizer + Poultry droppings + Rice husk \\
& RD & dust \\
VIII & CT & Control (No soil amendment) \\
\hline
\end{tabular}


fractions was measured by the hydrometer method as described by Gee and Bauder [16]. The clay obtained from particle size analysis with chemical dispersant is regarded as total clay (TC) and silt as total silt (TSilt), while clay and silt obtained after particle size analysis using deionised water only were the water-dispersible clay (WDC) and water-dispersible silt (WDSi). The soil organic carbon was determined by the Walkley and Black method described by [17]. Dispersion ratio which is an index of soil dispersion was calculated as;

Dispersion ratio $(\mathrm{DR})=[(\mathrm{WDSi}+\mathrm{WDC}) /(\mathrm{TSilt}+\mathrm{TC})](1)$

The higher the DR, the more the ability of the soil to disperse in water. The soil saturated hydraulic conductivity was measured using Klute and Dirksen method [18]. Soil bulk density was measured by the core method [19]. Total porosity (Tp) was obtained from bulk density $\left(\rho_{\mathrm{b}}\right)$ values with assumed particle density $\left(\rho_{\mathrm{s}}\right)$ of $2.65 \mathrm{Mg} / \mathrm{m}^{3}$ as follows,

$$
\text { Porosity }=\mathrm{Tp}=100\left(1-\rho_{\mathrm{b}} / \rho_{\mathrm{s}}\right)
$$

The soil moisture contents at 0.1 and $1.5 \mathrm{MPa}$ suction were determined by Klute [18] method while the available water capacity was calculated as the difference between moisture retention at 0.1 and $1.5 \mathrm{MPa}$ [i.e. field capacity (FC) and permanent wilting point (PWP)].

The method of Kemper and Rosenau [20] was used to separate the water-stable aggregates (WSA). In this method $40 \mathrm{~g}$ of $<4.75 \mathrm{~mm}$ air-dried soils were put in the topmost of a nest of four sieves of 2.00, 1.00, 0.50, and $0.25 \mathrm{~mm}$ mesh size and pre-soaked for $30 \mathrm{~min}$ in deionized water. Thereafter the nest of sieves and its contents were oscillated vertically in water 20 times using $4 \mathrm{~cm}$ amplitude at the rate of one oscillation per s. After wet-sieving, the resistant soil materials on each sieve and the unstable $(<0.25 \mathrm{~mm})$ aggregates were quantitatively transferred into beakers, dried in the oven until steady weight is achieved. The percentage ratio of the aggregates in each sieve represents the water-stable aggregates (WSA) of size classes; > 2.00, 2.00-1.00, 1.00-0.50, $0.50-0.25$ and $<0.25 \mathrm{~mm}$. Aggregate stability was measured as the mean-weight diameter (MWD) of stable aggregates as equation

$$
\mathrm{MWD}=\Sigma \mathrm{X}_{\mathrm{i}} \mathrm{W}_{\mathrm{i}}
$$

where $\mathrm{X}_{\mathrm{i}}$ is the mean diameter of the $\mathrm{i}^{\text {th }}$ sieve size and $\mathrm{W}_{\mathrm{i}}$ is the proportion of the total aggregates in the $i^{\text {th }}$ fraction. The higher the MWD values, the higher proportion of macroaggregates in the sample and therefore better stability.

\subsection{Data Analyses}

An analysis of variance of each soil properties between water management systems and amendments was performed on the soil data generated from the laboratory.
The differences among the mean values were tested with the LSD. Also correlation coefficients of the relationships between some of the soil properties were determined using the SPSS.10 computer package.

\section{Results and Discussion}

\subsection{The Influence of Water Managements and Amendments on Soil Bulk Density and Total Porosity}

During the first year of planting the bulk density was between $1.2 \mathrm{Mg} / \mathrm{m}^{3}$ to $1.46 \mathrm{Mg} / \mathrm{m}^{3}$ in the non sawah water management system and 1.19 to $1.46 \mathrm{Mg} / \mathrm{m}^{3}$ in the sawah system (Table 3). The results indicated that there was a significant difference within the bulk density with amendments. Also the mean bulk density of soils in the sawah system was significantly lower than the corresponding mean bulk density of the non sawah system. Higher bulk density according to Mbagwu et al. [9] signified compaction and undesirable soil structure that affects roots and plant growth negatively. Again, the same trend as was shown for bulk density in the first year was also indicated in the second year of planting. Bulk density varied significantly with amendments while a significant lower bulk density was obtained from the sawah system than the non sawah system. In all cases whether in sawah or non sawah management, rice husk dust reduced the mean bulk density of the soil. Nnabude and Mbagwu [11] showed that rice waste, either burnt or fresh condition could be effective in the improvement of soil properties. The importance of lower bulk density in the soil as portrayed by the sawah managed plots is the improvement of soil aeration, tilt and better water infiltration in addition to unreserved root penetration.

The total porosity also followed the trend in the soil bulk density (Table 3). While total porosity differed significantly with soil amendments in both first and second year of planting, it also differed significantly with water managements. In both years total porosity were always significantly higher in sawah managed system than in non sawah managed system (Table 3 ). The results here also showed the beneficial contribution of the organic amendments in improving the soil total porosity. Furthermore, sawah managed system could provide management strategies as to the improvement of soils liable to compaction and other negative physical properties when puddle for rice production.

\subsection{The Influence of Water Managements and Amendments on Moisture Content at Field Capacity (FC) and Wilting Point (WP)}

While amendments showed no significant differences with moisture content at field capacity (FC) in the first 
year, there was non significant difference in the $\mathrm{FC}$ values in the same year (Table 4). However, the value of $\mathrm{FC}$ in sawah system is higher when compared to non sawah. Also in the second year the FC did not differ sig nificantly with amendments and with water managements. Again the trend showed that although non significant, relatively higher value of FC was obtained in sawah than in non sawah managed plot. The inference that could be drawn from this is that sawah managed plots may hold water more at the level of field capacity than the non sawah managed. This hypothesis may be exploited in the restoration of these soils occurring within the inland valleys of the agro ecological zone in the area of water management for sustainable production.

In the first year just like the $\mathrm{FC}$, the moisture content at wilting point (WP) was significant with amendments but not with water management. However, the trend was that higher average value was obtained in the sawah managed plots more than the non sawah managed plot (Table 4). In the second year of planting, it was signifi- cant both for the amendment and water management. In most cases the amendments improved the moisture content at WP while sawah water management improved significantly the WP (Table 4). This result further confirms the superiority of sawah in soil moisture reserve over non sawah. In these soils which discharge its moisture contents very quickly, it will be an advantage that with sawah practice, more moisture may be reserved at $\mathrm{WP}$, than other practices.

\subsection{The Influence of Water Managements and Amendments on Soil Water-Stable Aggregates and Mean-Weight Diameter}

Table 5 presents Water-stable aggregate (WSA) sizes $>$ $2.00 \mathrm{~mm}$ and $<0.25 \mathrm{~mm}$. These two aggregate sizes were chosen because of their extreme vales and sizes. While the WSA $>2.00 \mathrm{~mm}$ were the large aggregates, the < $0.25 \mathrm{~mm}$ are the smallest aggregate sizes. The WSA $>$ $2.00 \mathrm{~mm}$ are not significant with neither amendment nor

Table 3. Effect of sawah system and amendments on bulk density and total porosity of 0-20 $\mathrm{cm}$ top soil.

\begin{tabular}{|c|c|c|c|c|}
\hline \multirow[b]{2}{*}{ Amendments } & \multicolumn{4}{|c|}{$1^{\text {st }}$ Year } \\
\hline & \multicolumn{2}{|c|}{ Non Sawah } & \multicolumn{2}{|c|}{ Sawah } \\
\hline & Bulk Density $\mathrm{Mg} / \mathrm{m}^{3}$ & Total Porosity $\%$ & Bulk Density $\mathrm{Mg} / \mathrm{m}^{3}$ & Total Porosity $\%$ \\
\hline $\mathrm{F}$ & 1.29 & 51.4 & 1.46 & 44.9 \\
\hline PD & 1.45 & 45.8 & 1.15 & 56.7 \\
\hline $\mathrm{RD}$ & 1.12 & 57.9 & 1.20 & 54.4 \\
\hline $\mathrm{RD}+\mathrm{PD}$ & 1.34 & 49.4 & 1.20 & 54.9 \\
\hline $\mathrm{PD}+\mathrm{F}$ & 1.31 & 50.2 & 1.29 & 51.4 \\
\hline $\mathrm{RD}+\mathrm{F}$ & 1.46 & 44.8 & 1.19 & 55.4 \\
\hline$F+P D+R D$ & 1.25 & 52.7 & 1.32 & 50.4 \\
\hline $\mathrm{CT}$ & 1.29 & 51.2 & 1.33 & 49.7 \\
\hline Mean & 1.31 & 50.4 & 1.27 & 52.2 \\
\hline $\operatorname{LSD}(0.05)$ & 0.14 & 5.9 & 0.14 & 5.9 \\
\hline \multicolumn{2}{|c|}{ Non Sawah $\times$ Sawah Bulk density } & 0.03 & & \\
\hline \multicolumn{2}{|c|}{ Non Sawah $\times$ Sawah Total porosity } & 1.12 & & \\
\hline & \multicolumn{4}{|c|}{$2^{\text {nd }}$ Year } \\
\hline $\mathrm{F}$ & 1.25 & 52.8 & 1.35 & 48.9 \\
\hline PD & 1.31 & 50.8 & 1.13 & 57.5 \\
\hline $\mathrm{RD}$ & 1.13 & 57.1 & 1.23 & 53.5 \\
\hline $\mathrm{RD}+\mathrm{PD}$ & 1.27 & 51.9 & 1.18 & 55.7 \\
\hline $\mathrm{PD}+\mathrm{F}$ & 1.30 & 50.6 & 1.23 & 53.5 \\
\hline $\mathrm{RD}+\mathrm{F}$ & 1.45 & 45.3 & 1.13 & 57.0 \\
\hline $\mathrm{F}+\mathrm{PD}+\mathrm{RD}$ & 1.26 & 52.7 & 1.28 & 51.6 \\
\hline $\mathrm{CT}$ & 1.27 & 52.1 & 1.28 & 51.7 \\
\hline Mean & 1.28 & 51.7 & 1.23 & 53.7 \\
\hline $\operatorname{LSD}(0.05)$ & 0.10 & 3.9 & 0.10 & 3.9 \\
\hline \multicolumn{2}{|c|}{ Non Sawah $\times$ Sawah Bulk density } & 0.026 & & \\
\hline \multicolumn{2}{|c|}{ Non Sawah $\times$ Sawah Total porosity } & 1.12 & & \\
\hline
\end{tabular}

$\mathrm{NS}=$ non-significant 
Table 4. Effect of sawah system and amendments on moisture content at field capacity (FC) and wilting point (WP) of 0-20 cm top soil.

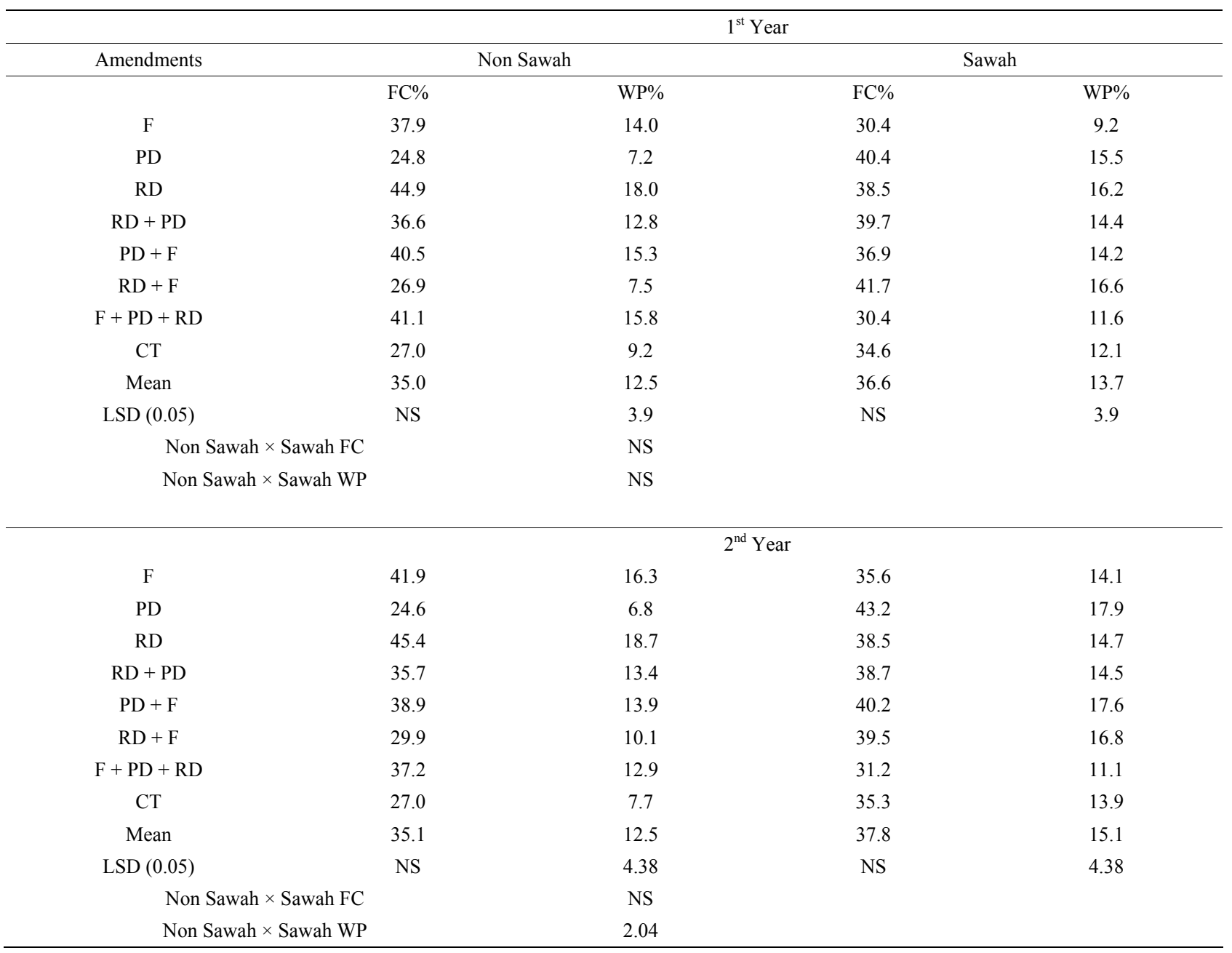

$\mathrm{NS}=$ non-significant

water managements. In the $<0.25 \mathrm{~mm}$ aggregate sizes in the first year, amendments contributed significantly in increasing the values which were not desirable as aggregates within these range are said to be very unstable especially when submerged [6,21]. The WSA $<0.25 \mathrm{~mm}$ were also not significant with water management. In the second year WSA reduced significantly in sawah management and differed significantly with amendment (Table 5). Average value shows that in non sawah WSA was $13.69 \%$ in the second year and went down to $9.97 \%$ in the sawah system. This was an advantage as AbuHamdeh et al. [22] observed that as clod size increased, detachment rate increased and interaggregate tensile strength decreased and often leading to greater rate of splash erosion. The WSA $<0.25 \mathrm{~mm}$ correspondingly increased in sawah managed over non sawah managed in the second year significantly (Table 5).

Mean-weight diameter (MWD) did not change signi- ficantly with water management and amendments in the first year (Table 5). In the second year of planting MWD changed significantly with amendments and water managements. In the non sawah management an average value of $0.75 \mathrm{~mm}$ was obtained as against an average of $0.56 \mathrm{~mm}$ in sawah managed plots. These lower values of MWD in sawah managed plots may be advantageous when considered in the entire dynamics of low land or flooded rice production. This condition may be more favourable to rice requirements in terms of the physical soil condition to enable puddling.

\subsection{The Influence of Water Managements and Amendments on Soil Dispersion Ratio and Saturated Hydraulic Conductivity}

Dispersion ratio (DR) is an index which measures the ease of soil particles to disperse and erode, indicates that 
higher values of DR signify higher propensity to erode especially when submerged. Table 6 among other properties showed the DR with amendments and with water managements. In the first year of operation amendments contributed significantly to changes in DR but not in water managements. However lower average value of DR was obtained in sawah managed. In the second year both the amendments and the water managements contributed significantly to DR. An average DR value of 0.78 was obtained in non sawah managed plot while a mean value of 0.58 was for sawah system. The implication of these results are that although low values of MWD and high WSA $<0.25 \mathrm{~mm}$ were obtained in $s a$ wah managed soils, yet their rate of potential erodibility was low. Igwe [6] and Igwe [7] used this index to show the potential soil loss values for similar soils within the agro ecological zone.

Although the saturated hydraulic conductivity $(K S)$ was not significant with water management in first and second years, yet the amendments were able to change the saturated hydraulic conductivity significantly (Table 6). In both year $K s$ was always nominally higher in sawah managed plots than the non sawah plots. This was a reflection of the earlier results on bulk density, total porosity and aggregate stability of the soils.

\subsection{Relationships among the Soil Physical Properties}

In the first year of planting irrespective of the type of water managements, bulk density which is a very strong index of the soil structure negatively correlated with total porosity, moisture contents at field capacity (FC) and

Table 5. Effect of sawah system and amendments on large Water-stable aggregates (WSA $>2.00$ mm), fine aggregates (WSA $<0.25 \mathrm{~mm}$ ) and mean-weight diameter (MWD) of 0-20 cm top soil.

\begin{tabular}{|c|c|c|c|c|c|c|}
\hline & & & & $1^{\text {st }}$ Year & & \\
\hline & & Ion-Sawah & & & Saw & \\
\hline & WSA $>2.0$ & $\mathrm{WSA}<0.25$ & MWD & WSA $>2.0$ & $\mathrm{WSA}<0.25$ & MWD \\
\hline $\mathrm{F}$ & 5.2 & 77.9 & 0.39 & 7.89 & 71.8 & 0.48 \\
\hline PD & 6.25 & 72.3 & 0.43 & 5.95 & 73.4 & 0.43 \\
\hline $\mathrm{RD}$ & 9.21 & 71.9 & 0.53 & 7.04 & 70.6 & 0.50 \\
\hline $\mathrm{RD}+\mathrm{PD}$ & 7.97 & 71.3 & 0.51 & 6.16 & 75.0 & 0.42 \\
\hline$P D+F$ & 9.00 & 69.6 & 0.52 & 8.71 & 68.2 & 0.53 \\
\hline $\mathrm{RD}+\mathrm{F}$ & 7.73 & 69.8 & 0.49 & 5.04 & 74.1 & 0.40 \\
\hline$F+P D+R D$ & 9.53 & 64.9 & 0.55 & 5.69 & 72.3 & 0.42 \\
\hline $\mathrm{CT}$ & 9.51 & 69.5 & 0.55 & 6.57 & 74.0 & 0.44 \\
\hline Mean & 8.05 & 70.9 & 0.50 & 6.63 & 72.4 & 0.45 \\
\hline $\operatorname{LSD}(0.05)$ & NS & 6.2 & NS & NS & 6.2 & NS \\
\hline Non-Sawah $\times$ Sawah WSA $>2.00 \mathrm{~mm}$ & & & & NS & & \\
\hline Non-Sawah $\times$ Sawah WSA $<0.25 \mathrm{~mm}$ & & & & NS & & \\
\hline Non-Sawah $\times$ Sawah MWD & & & & NS & & \\
\hline & & & & $2^{\text {nd }}$ Year & & \\
\hline $\mathrm{F}$ & 15.9 & 60.5 & 0.80 & 9.13 & 67.7 & 0.58 \\
\hline PD & 14.4 & 59.2 & 0.82 & 13.5 & 64.6 & 0.71 \\
\hline RD & 11.9 & 60.5 & 0.70 & 10.7 & 68.9 & 0.58 \\
\hline $\mathrm{RD}+\mathrm{PD}$ & 14.8 & 60.3 & 0.76 & 9.0 & 68.2 & 0.55 \\
\hline $\mathrm{PD}+\mathrm{F}$ & 15.6 & 56.6 & 0.83 & 8.4 & 67.1 & 0.54 \\
\hline $\mathrm{RD}+\mathrm{F}$ & 11.4 & 60.9 & 0.66 & 8.8 & 66.3 & 0.55 \\
\hline $\mathrm{F}+\mathrm{PD}+\mathrm{RD}$ & 11.8 & 59.4 & 0.67 & 8.8 & 67.7 & 0.54 \\
\hline CT & 13.7 & 61.9 & 0.72 & 9.8 & 66.9 & 0.59 \\
\hline Mean & 13.69 & 59.9 & 0.75 & 9.97 & 67.2 & 0.58 \\
\hline $\operatorname{LSD}(0.05)$ & 4.86 & 5.78 & 0.18 & 4.86 & 5.78 & 0.18 \\
\hline Non-Sawah $\times$ Sawah WSA $>2.00 \mathrm{~mm}$ & & & & 3.64 & & \\
\hline Non-Sawah $\times$ Sawah WSA $<0.25 \mathrm{~mm}$ & & & & 4.2 & & \\
\hline Non-Sawah $\times$ Sawah MWD & & & & 0.10 & & \\
\hline
\end{tabular}

$\mathrm{NS}=$ non-significant 
Table 6. Effect of sawah system and amendments on Dispersion ratio (DR) and saturated hydraulic conductivity (Ks) of 0-20 cm top soil.

\begin{tabular}{|c|c|c|c|c|c|}
\hline \multirow{3}{*}{ Amendments } & & \multicolumn{4}{|c|}{$1^{\text {st }}$ Year } \\
\hline & & \multicolumn{2}{|c|}{ Non Sawah } & \multicolumn{2}{|c|}{ Sawah } \\
\hline & & DR & $K s(\mathrm{~cm} / \mathrm{h})$ & DR & $K s(\mathrm{~cm} / \mathrm{h})$ \\
\hline $\mathrm{F}$ & & 0.47 & 5.07 & 0.66 & 7.61 \\
\hline PD & & 0.61 & 5.34 & 0.42 & 12.9 \\
\hline $\mathrm{RD}$ & & 0.72 & 15.1 & 0.67 & 21.5 \\
\hline $\mathrm{RD}+\mathrm{PD}$ & & 0.67 & 3.43 & 0.78 & 12.7 \\
\hline$P D+F$ & & 0.80 & 21.3 & 0.70 & 4.80 \\
\hline $\mathrm{RD}+\mathrm{F}$ & & 0.73 & 14.9 & 0.65 & 11.6 \\
\hline$F+P D+R D$ & & 0.66 & 20.8 & 0.79 & 11.7 \\
\hline $\mathrm{CT}$ & & 0.74 & 6.6 & 0.62 & 10.9 \\
\hline Mean & & 0.68 & 11.6 & 0.66 & 11.7 \\
\hline $\operatorname{LSD}(0.05)$ & & 0.16 & 9.4 & 0.16 & 9.4 \\
\hline Non Sawah $\times$ Sawah DR & & & NS & & \\
\hline \multirow[t]{2}{*}{ Non Sawah $\times$ Sawah Ks } & & & NS & & \\
\hline & & \multicolumn{3}{|c|}{$2^{\text {nd }}$ Year } & \\
\hline $\mathrm{F}$ & & 0.63 & 6.16 & 0.41 & 10.8 \\
\hline PD & & 0.78 & 8.18 & 0.58 & 14.6 \\
\hline $\mathrm{RD}$ & & 0.86 & 19.0 & 0.65 & 25.7 \\
\hline $\mathrm{RD}+\mathrm{PD}$ & & 0.87 & 6.36 & 0.67 & 14.4 \\
\hline $\mathrm{PD}+\mathrm{F}$ & & 0.82 & 22.8 & 0.69 & 9.89 \\
\hline $\mathrm{RD}+\mathrm{F}$ & & 0.81 & 15.6 & 0.35 & 13.5 \\
\hline$F+P D+R D$ & & 0.74 & 24.14 & 0.49 & 19.3 \\
\hline $\mathrm{CT}$ & & 0.76 & 7.29 & 0.76 & 12.6 \\
\hline Mean & & 0.78 & 13.7 & 0.58 & 15.1 \\
\hline \multirow[t]{3}{*}{$\operatorname{LSD}(0.05)$} & & 0.18 & 9.6 & 0.18 & 9.6 \\
\hline & Non Sawah $\times$ Sawah DR & & 0.18 & & \\
\hline & Non Sawah $\times$ Sawah $K s$ & & NS & & \\
\hline
\end{tabular}

$\mathrm{NS}=$ non-significant

wilting point (WP) (Table 7). Also in the first year total porosity positively correlated with FC and WP, while FC positively correlated with saturated hydraulic conductivity $(K s)\left(\mathrm{r}=0.44^{*}\right)$. Again the WP positively correlated significantly with $K s\left(\mathrm{r}=0.47^{*}\right)$. The levels of significant correlation within the WSA are shown. However, the dispersion ratio (DR) positively correlated significantly with MWD $\left(r=0.43^{*}\right)$.

In the second year the significant negative correlation between bulk density, FC and WP were also obtained (Table 7). Positive significant correlations were also obtained between the total porosity, FC and WP thus indicating the importance of soil moisture contents in the formation of soil structure generally and these soils in particular. Also trend of correlations found between the positively with MWD $(\mathrm{r}=0.52 *)$ When all the results obtained for the two years were WSA in the first year also repeated in the second year. Again the dispersion ratio (DR) significantly correlated combined the relationships among the soil properties took a different shape.
In these combined results soil organic carbon assumed a different role than the ones obtained for individual years. Table 7 also shows the correlation matrix for the years combined. Soil organic carbon (OC) negatively correlated with bulk density $\left(\mathrm{r}=-0.40^{*}\right)$ and WSA $<0.25 \mathrm{~mm}$ $\left(\mathrm{r}=-0.49^{*}\right)$. OC also positively correlated significantly with total porosity, WSA $>2.00 \mathrm{~mm}$, MWD and saturated hydraulic conductivity $(K s)$. The implication of these is that the overall effect of $\mathrm{OC}$ can be viewed from its cumulative contribution rather than the immediate action. In a degraded Ultisol in southeastern Nigeria. Mbagwu (1992) highlighted the roles of organic amendments in improving the soil structure and perhaps the fertility supply. As in the individual years the bulk density significantly correlated negatively with $\mathrm{FC}$ and WP while Ks positively correlated significantly with $\mathrm{FC}(\mathrm{r}=$ $\left.0.34^{*}\right)$ and WP $\left(r=0.31^{*}\right)$. This result showed that the moisture contents of the soil to a large extent control the $K s$ which in addition are a function of the soil bulk density. 
As a result of the importance of bulk density as a soil structural index, it was subjected further to regression analyses aimed at determining the properties determined that influenced it most. The correlation coefficients that were high were selected for this analysis. The results for the first year, second year and the two years combined are presented (Table 8). In the first year the moisture contents at FC and WP explained about $81 \%$ of the variation in bulk density while individually WP explained $78 \%$ and $\mathrm{FC} 67 \%$ of the variation in bulk density. It follows that both FC and WP could be used to predict or estimate the bulk density of this soil. During the sec- ond year the $\mathrm{R}^{2}$ for $\mathrm{FC}$ and WP were not as high as in the first year with both FC and WP explaining $45 \%$ or less of the variability in bulk density. An analyses of DR in the second year as a determinant of degradation showed that the properties that had correlated significantly with gave low $\mathrm{R}^{2}$ values (Table 8). In the combined years (Table 8), both FC and WP jointly explained about $61 \%$ of the variation in bulk density. Individually FC and WP explained $56 \%$ and $61 \%$ respectively of the variation in bulk density of the soils. The contribution of WP in this cumulative determination may be linked to other factors such as clay contents and other intrinsic chemical prop-

Table 7. Correlation coefficients matrix of soil physical properties.

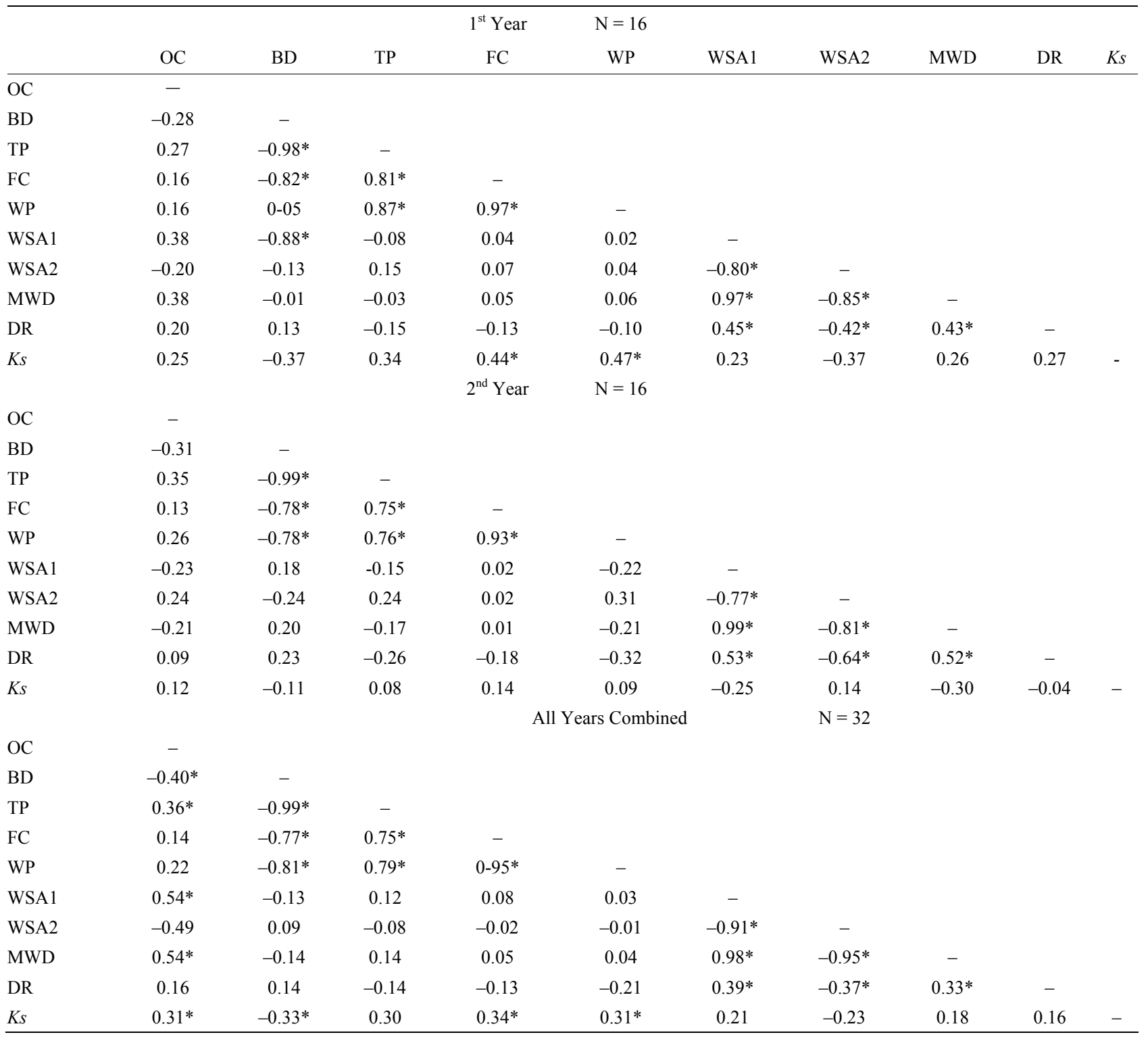

$\mathrm{OC}=$ organic carbon; $\mathrm{BD}=$ bulk density; $\mathrm{TP}=$ total porosity $\mathrm{FC}=$ field capacity; $\mathrm{WP}=$ wilting point; WSA1\& $2=\mathrm{WSA}>2.00,<0.25 \mathrm{~mm}$ respectively: $\mathrm{DR}=$ dispersion ratio; Ks hydraulic conductivity; *Significant at $\mathrm{p}>0.05$ 
Table 8. Linear regression relationships between bulk density, dispersion ratio and other physical properties.

\begin{tabular}{|c|c|c|}
\hline Regression Equation & $\mathrm{R}^{2}$ & SE \\
\hline \multicolumn{3}{|l|}{$1^{\text {st }}$ Year } \\
\hline $\mathrm{BD}=1.796-0.014 \mathrm{FC}$ & 0.67 & 0.062 \\
\hline $\mathrm{BD}=1.65-0.028 \mathrm{WP}$ & 0.78 & 0.051 \\
\hline $\mathrm{BD}=1.50+0.013 \mathrm{FC}-0.05 \mathrm{WP}$ & 0.81 & 0.049 \\
\hline \multicolumn{3}{|l|}{$2^{\text {nd }}$ Year } \\
\hline $\mathrm{BD}=1.48-0.02 \mathrm{WP}$ & 0.44 & 0.07 \\
\hline $\mathrm{BD}=1.61-0.01 \mathrm{FC}$ & 0.45 & 0.065 \\
\hline $\mathrm{BD}=1.56-0.006 \mathrm{FC}-0.006 \mathrm{WP}$ & 0.45 & 0.07 \\
\hline $\mathrm{DR}=0.24+0.66 \mathrm{MWD}$ & 0.24 & 0.14 \\
\hline $\mathrm{DR}=2.26-0.03 \mathrm{WSA}<0.25 \mathrm{~mm}$ & 0.41 & 0.12 \\
\hline $\mathrm{DR}=0.31+0.32 \mathrm{WSA}>2.00 \mathrm{~mm}$ & 0.28 & 0.14 \\
\hline $\mathrm{DR}=2.98+0.06 \mathrm{WSA}>2.00 \mathrm{~mm}-\mathrm{WSA}<0.25 \mathrm{~mm}-1.49 \mathrm{MWD}$ & 0.47 & 0.13 \\
\hline \multicolumn{3}{|l|}{ Two Years Combined } \\
\hline $\mathrm{BD}=1.57-0.022 \mathrm{WP}$ & 0.61 & 0.061 \\
\hline $\mathrm{BD}=1.71-0.012 \mathrm{FC}$ & 0.56 & 0.065 \\
\hline $\mathrm{BD}=1.54+0.002 \mathrm{FC}-0.03 \mathrm{WP}$ & 0.61 & 0.06 \\
\hline
\end{tabular}

erties not determined.

\section{Conclusions}

The study revealed the following

1) Sawah managed soils reduced significantly the soil bulk density and thereby increasing the soil total porosity.

2) Well managed water regime can also on the long run improve the WP, water-stable aggregates and the MWD of the soils

3) In spite of the destruction of soil structure as a result of cultural practices during rice cultivation the DR is improved on the long run by sawah water management.

4) Moisture contents at FC and WP relates significantly with soil bulk density which also relates nega tively with total porosity. However, FC and WP may be very good tools in the estimation of bulk density. Again, the amendments were identified as promoting the development of soil aggregates and $K s$ on a long term. Arising from the study, a number of possible further researches have been suggested for the development of yield in water stress area in the sub-Saharan Africa and the comparison of pump water supply from lakes, rain fed and gravity irrigation from adjacent lakes or streams in rice cultivation.

\section{References}

[1] T. Wakatsuki, M. M. Buri and O. O. Fashola, "Ecological Engineering for Sustainable Rice Production and the Restoration of Degraded Watersheds in West Africa," Proceedings of Rice Research Conference, Bali, 12-14 September 2005, pp. 336-366.
[2] T. Wakatsuki and T. Masunaga, "Ecological Engineering for Sustainable Food Production of Degraded Watersheds in Tropics of Low pH Soils: Focus on West Africa," Soil Science and Plant Nutrition, Vol. 51, No. 5, 2005, pp. 629-636.

[3] J. S. C. Mbagwu, "The Agricultural Soils of Nigeria: Properties and Agronomic Significance for Increased Productivity," Beitrage für Tropical Landwirtschaften und Veterinari Medizin, Vol. 27, 1989, pp. 395-409.

[4] J. S .C. Mbagwu, "Improving the Productivity of a Degraded Ultisol in Nigeria Using Organic and Inorganic Amendments. Part 2: Changes in Physical Properties," Bioresource Technology, Vol. 42, No. 3, 1992, pp. 167175.

[5] S. Hirose and T. Wakatsuki, "Restoration of Inland Valley Ecosystems in West Africa," Norin Tokei Kyokai, Tokoyo, 2002, p. 572.

[6] C. A. Igwe, "Erodibility of Soils of the Upper Rainforest Zone, Southeastern Nigeria," Land degradation \& Development, Vol. 14, No. 3, 2003, pp. 323-334.

[7] C. A. Igwe, "Erodibility in Relation to Water-Dispersible clay for Some Soils of Eastern Nigeria," Land degradation \& Development, Vol. 16, No. 1, 2005, pp. 87-96.

[8] R. Lal, "Soil Erosion Problems on Alfisols in Western Nigeria. VI. Effects of Erosion on Experimental Plots," Geoderma, Vol. 25, No. 3-4, 1981, pp. 215-230.

[9] J. S. C. Mbagwu, R. Lal and T. W. Scott, "Effects of Desurfacing Alfisols and Ultisols in Southern Nigeria. II. Changes in Soil Physical Properties," Soil Science Society of America Journal, Vol. 48, 1984, pp. 834-838.

[10] P. Rengasamy, R. S. B. Greene, G. W. Ford and A. H. Mehanni, "Identification of Dispersive Behaviour and Management of Red-Brown Earths," Australian Journal of Soil Research, Vol. 22, No. 4, 1984, pp. 413-431.

[11] P. C. Nnabude and J. S. C. Mbagwu, "Soil Water Rela- 
tions of a Nigerian Typic Haplustult Amended with Fresh and Burnt Rice-Mill Wastes," Soil \& Tillage Research, Vol. 50, No. 3-4, 1999, pp. 207-214.

[12] A. K. Makarim, D. K. Cassel and M. K. Wade, "Effect of Land Reclamation Practices on Chemical Properties of an Acid, Infertile Oxisol in Western Sumatra," Soil Technology, Vol. 2, 1989, pp. 27-39.

[13] D. K. Cassel, M. K. Wade and A. K. Makarim, "Crop Response to Management of a Degraded Oxisol Site in West Sumatra," Soil Technology, Vol. 3, No. 2, 1990, pp. 99- 112.

[14] J. C. Nwite, C. A. Igwe and T. Wakatsuki, "Evaluation of Sawah Rice Management System in an Inland Valley in Southeastern Nigeria. I: Soil Chemical Properties and Rice Yield," Paddy and Water Environment, Vol. 6, No. 3, 2008, pp. 299-307.

[15] S. S. Abe, T. Masunaga, S. Yamamoto, T. Honna and T. Wakatsuki, "Comprehensive Assessment of the Clay Mineralogical Composition of Lowland Soils in West Africa," Soil Science and Plant Nutrition, Vol. 52, No. 4, 2006, pp. 479-488.

[16] G. W. Gee and J. W. Bauder, "Particle-size Analysis," In: A. Klute Ed., Methods of Soil Analysis, Part 1, American Society of Agronomy, Madison, 1986, pp. 91-100.
[17] D. W. Nelson and L. E. Sommers, "Total Carbon, Organic Carbon and Organic Matter,” In: A. L. Page, R. H. Miller, D. R. Keeney, Eds., Methods of Soil Analysis, Part 2, America Society of Agronomy, Madison, 1982, pp. 539-579.

[18] A. Klute and C. Dirksen, "Hydraulic Conductivity and Diffusivity," In: A. Klute, Ed., Methods of Soil Analysis, Part 1, American Society of Agronomy, Madison, 1986, pp. 694-783.

[19] G. R. Blake and K. H. Hartge, "Bulk Density," In: A. Klute, Ed., Methods of Soil Analysis, Part 1, American Society of Agronomy, Madison, 1986, pp 363-382.

[20] D. W. Kemper and R. C. Rosenau, "Aggregate Stability and Size Distribution,” In: A. Klute, Ed., Methods of Soil Analysis, Part 1, American Society of Agronomy, Madison, 1986, pp. 425-442.

[21] C. A. Igwe, F. O. R. Akamigbo and J. S. C. Mbagwu, "Physical Properties of Soils of Southeastern Nigeria and the Role of Some Aggregating Agents in their Stability," Soil Science, Vol. 160, No. 6, 1995, pp. 431-441.

[22] N. H. Abu-Hamdeh, S. A. Abo-Qudais and A. M. Othman. "Effect of Soil Aggregate Size on Infiltration and Erosion Characteristics," European Journal of Soil Science, Vol. 57, No. 5, 2006, pp. 609-616. 